\title{
Effect of Feeding Rice Gluten Meal (RGM) on Haematological, Serum Biochemical and Carcass Traits in Broilers
}

\author{
O.P. Dinani*, Pramod Kumar Tyagi, A.B. Mandal, Praveen Kumar Tyagi, \\ J.S. Tyagi and Dukare Sagar Popat \\ ICAR-Central Avian Research Institute, Izatnagar, Bareilly, U.P, 243122, India \\ *Corresponding author
}

\section{A B S T R A C T}

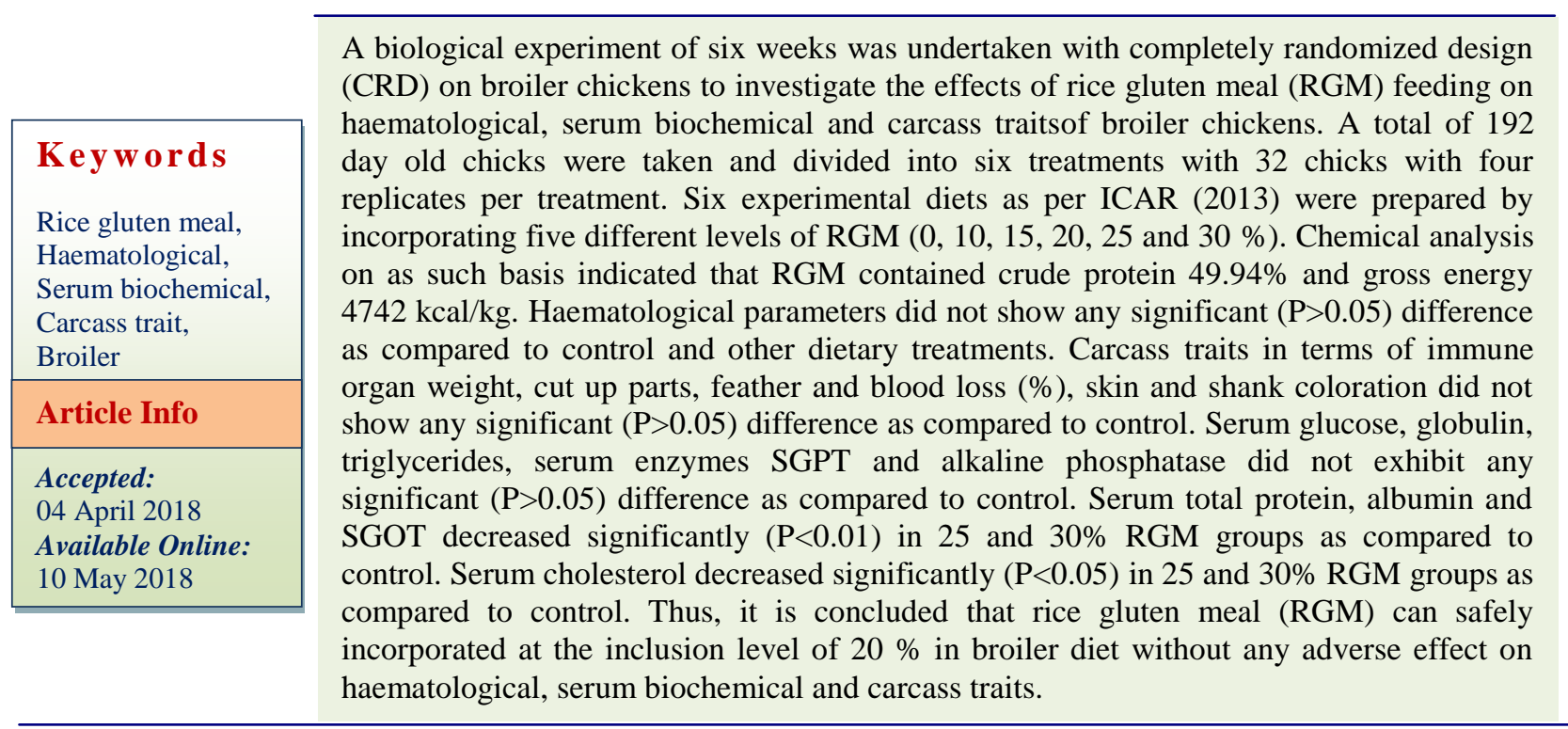

\section{Introduction}

Poultry industry is the fastest growing sector in Indian agriculture. Feed is the major constituent in the poultry production accounts for $65-75 \%$ of total recurring expenditure. Feed costs are primarily driven by the cost of protein sources. Substitution of expensive protein sources with lower cost ingredients would potentially reduce the cost of the feed. Soybean meal (SBM) is the major protein source used in poultry diet. Instability in its production, indiscriminate exports and higher demand has resulted in its shortage for the poultry industry leading to its higher price. Substitution of SBM at reasonable price will lead to economic broiler production.

India is second largest producers of rice in world after China, producing approximately 106.65 MT rice in 2013-14 (Agriculture statistics, 2015-16). Now days, certain newer 
rice by products are available in appreciable quantities and cheaper rate that can be utilized from rice processing industries such as rice gluten meal (RGM). Rice gluten meal is a byproduct of wet-milling of rice obtained after starch extraction and syrup preparation. It is relatively a new feedstuff having brownish color and coarse powdery texture. Initial research finding showed that RGM can be included up to $10 \%$ level in broiler chicken without affecting feed efficiency and dressing percentage (Sherazi et al., 1995). Metwally and Farahat (2015) found that broiler fed RGM with different inclusion rates up to $12.5 \%$ had the same growth performance, carcass traits and serological parameters. Kumar et al., (2016) found that RGM could replace ground nut cake (GNC) in the concentrate mixture of growing calves up to $75 \%$ level without any adverse effect on growth performance and serological parameters. Malik et al., (2017) reported that replacement of ground nut cake (GNC) by RGM and maize gluten meal (MGM) at 75\% level did not differ in feed efficiency and average daily gain (ADG) in growing Sahiwal cattle. Thus, regarding feeding value of rice gluten meal (RGM) very scanty research is available and no research is available regarding effect of feeding RGM on haematological, serum biochemical and carcass traits in broilers up to $30 \%$ inclusion level. So, there is need to evaluate RGM effect of feeding RGM on haematological, serum biochemical and carcass traits in broilers due to its increased availability as low cost feed source.

\section{Materials and Methods}

The research work carried out at the Division of Avian Nutrition and Feed Technology, ICAR-Central Avian Research Institute (CARI), Izatnagar, India in the year 2018. The study was carried out as per the guidelines and approval of Institute Animal Ethical
Committee (IAEC) and Committee for the purpose of control and supervision of experiments on animals (CPCSEA).

\section{Experimental design}

A biological experiment of six weeks was undertaken with completely randomized design (CRD) on broiler chickens (CARIBRO Vishal) to investigate the effects of rice gluten meal (RGM) feeding on haematological, serum biochemical and carcass traits in broilers. A total of 192 day old chicks were taken and divided into six groups with 32 chicks in each treatment. Each replicate consists of 8 chicks housed together in battery cages and 4 replicates allocated for each treatment.

\section{Experimental diets}

Six experimental broiler diets iso-caloric and iso-nitrogenous were prepared by incorporating different levels of rice gluten meal $(0,10,15,20,25$ and $30 \%)$ with as per ICAR (2013) standard. The diets along with all the used ingredients including rice gluten meal were analyzed for proximate (AOAC, 2000), calcium (Talpatra et al., 1940) and fibre fractions (Van Soest and Wine, 1967). In vitro pepsin-pancreatin digestibility of RGM and soybean meal was measured according to the method of Gopalkrishnan and Prakash (2000). Mycotoxin (aflatoxin B1 and ochratoxin) screening has been done by thin layer chromatography (AOAC, 2000) for RGM.

\section{Haematological parameters}

Haematological parameters were estimated using Abacus junior vet 5 haemo-analyser (Datron, Ltd.). Blood in 1\% EDTA were collected from eight birds per treatment at the time of slaughter (42 days).Total leukocytes count (TLC), Differential leukocytes count 
(DLC), Total RBC count, Hb, PCV, MCV, $\mathrm{MCH}, \mathrm{MCHC}, \mathrm{RBC}$ distribution width (RDWc), platelet count, platelet \%, MPV and platelet distribution width (PDWc) were recorded from each samples.

\section{Serological parameters}

Serum glucose, total protein, albumin, globulin cholesterol, triglycerides, serum enzymes SGOT, SGPT and alkaline phosphatase were estimated using standard procedures through commercial diagnostic kits.

\section{Carcass traits}

At the time of slaughter (42th day) one male and one female broiler from each replicate group were selected for determination of carcass traits in terms of immune organ weight cut up parts, feather and blood loss (\%), skin and shank coloration. All of the data regarding organ weight, cut up parts and length were expressed per kilogram of BW. Skin and shank coloration were measured by Roach color fan (Scale 1-15),

\section{Statistical analysis}

Data was subjected to test of significance as per complete randomized design (Snedecor and Cochran, 1989). Treatments means were separated using Duncan's multiple range test (Duncan, 1955). The SPSS (Statistical Package for the Social Sciences) software program (IBM Corporation, Somers, NY, USA) version 16.0 used for analysis of data.

\section{Results and Discussion}

\section{Chemical composition of test material and diets}

Experimental diets ingredients and nutrient composition as prestarter (0-2 wk) and starter
(2-3 wk) diets have been given in table 1 and finisher diets (3-6 wk) in table 2 as per ICAR (2013) feeding standard.

RGM used in this experiment was analyzed and contained (\%) Moisture 7.64, Dry matter (DM) 92.36,Crude protein (CP) 49.94, Ether extract (EE) 5.79, Crude fiber (CF) 7.43, Total ash (TA) 3.31, Acid insoluble ash (AIA) 0.89, Nitrogen free extract (NFE) 33.53, Calcium 0.84, Phosphorus 0.98, Neutral detergent fiber (NDF) 43.41, Acid detergent fiber (ADF) 16.24, Acid detergent soluble (ADS) 27.17, Acid detergent lignin (ADL) 1.54 and Gross energy (kcal/kg) 4742 on as basis. In vitro pepsin-pancreatic digestibility (IVPPD) of RGM was found $81.92 \%$ while IVPPD of soybean meal was observed $88.15 \%$. No detectable aflatoxin B1 and ochratoxin has been found in RGM.

Metwally and Farhat (2015) reported higher value of RGM in terms of protein $(57.60 \%)$, but lower values of RGM in terms of $\mathrm{EE}$ $(3.16 \%)$ and CF $(1.45 \%)$ as compared to our results. Similarly Kumar et al., (2016) reported lower values of RGM in terms of protein $(46.40 \%)$ and EE $(3.40 \%)$ as compared to our results. Furthermore, the drying process can have crucial influence not only on variability of nutrients but also on concentration and availability of nutrients in different samples.

\section{Haematological parameters}

The data pertaining to influence of different levels of RGM feeding to broilers on haematological parameters have been presented in table 3. Total leukocytes count (TLC), Differential leukocytes count (DLC), Total RBC count, Hb, PCV, MCV, MCH, $\mathrm{MCHC}, \mathrm{RBC}$ distribution width (RDWc), platelet count, platelet $\%, \mathrm{MPV}$ and platelet distribution width (PDWc) were recorded from each samples. 
Table.1 Ingredients and nutrient composition of pre-starter starter diets for different level of RGM

\begin{tabular}{|c|c|c|c|c|c|c|c|c|c|c|c|c|}
\hline \multicolumn{7}{|c|}{ Pre-Starter Diets (0-2 wk) } & \multicolumn{6}{|c|}{ Starter Diets (2-3 wk) } \\
\hline Ingredients & D1 & D2 & D3 & D4 & D5 & D6 & D1 & D2 & D3 & D4 & D5 & D6 \\
\hline Maize & 54.32 & 58.0 & 59.8 & 61.0 & 59.0 & 57.5 & 55.63 & 59 & 59.92 & 61.42 & 62.7 & 60.75 \\
\hline SBM & 38 & 26.50 & 20.40 & 14.60 & 8.60 & 2.20 & 37.1 & 25.2 & 19.3 & 13.24 & 7.2 & 1.2 \\
\hline DORB & 0 & 0 & 0.00 & 0.00 & 2.90 & 5.70 & 0 & 0 & 0.5 & 0.7 & 1 & 3.8 \\
\hline Oil & 3.10 & 1.40 & 0.60 & 0.00 & 0.00 & 0.00 & 3.5 & 2 & 1.4 & 0.65 & 0 & 0 \\
\hline RGM & 0 & 10 & 15.00 & 20.00 & 25.00 & 30.00 & 0 & 10 & 15 & 20 & 25 & 30 \\
\hline LSP & 1.40 & 1.30 & 1.30 & 1.30 & 1.30 & 1.30 & 1.35 & 1.37 & 1.32 & 1.3 & 1.27 & 1.26 \\
\hline DCP & 1.82 & 2 & 2 & 2 & 2 & 2 & 1.55 & 1.6 & 1.7 & 1.76 & 1.8 & 1.85 \\
\hline Lysine & 0 & 0 & 0.1 & 0.2 & 0.3 & 0.5 & 0 & 0 & 0.06 & 0.16 & 0.26 & 0.37 \\
\hline Methionine & 0.2 & 0.1 & 0.1 & 0.0 & 0.0 & 0.0 & 0.1 & 0.06 & 0.03 & 0 & 0 & 0 \\
\hline Constant* & 0.765 & 0.765 & 0.765 & 0.765 & 0.765 & 0.765 & 0.765 & 0.765 & 0.765 & 0.765 & 0.765 & 0.765 \\
\hline Total & 100.00 & 100.00 & 99.995 & 99.975 & 100.015 & 100.015 & 100.00 & 100.00 & 100.00 & 100.00 & 100.00 & 100.00 \\
\hline \multicolumn{13}{|c|}{ Nutrient composition (\%) } \\
\hline $\mathbf{C P}$ & 21.97 & 22.01 & 21.97 & 21.98 & 22.04 & 21.98 & 21.51 & 21.52 & 21.53 & 21.51 & 21.49 & 21.53 \\
\hline $\mathrm{ME}$ (kcal/kg)*** & 3003.2 & 3000.4 & 2998.2 & 3000.1 & 2998.6 & 3002.3 & 3049.7 & 3053.4 & 3053.4 & 3050.4 & 3051.0 & 3049.2 \\
\hline $\mathbf{C a}$ & 1.03 & 1.00 & 1.00 & 1.02 & 1.03 & 1.03 & 0.95 & 0.95 & 0.95 & 0.95 & 0.95 & 0.96 \\
\hline$\overline{\mathbf{P}}$ & 0.45 & 0.45 & 0.44 & 0.45 & 0.45 & 0.45 & 0.40 & 0.39 & 0.40 & 0.40 & 0.40 & 0.40 \\
\hline Lysine & 1.18 & 1.20 & 1.19 & 1.19 & 1.19 & 1.18 & 1.31 & 1.15 & 1.09 & 1.08 & 1.07 & 1.07 \\
\hline Methionine & 0.52 & 0.52 & 0.52 & 0.51812 & 0.52 & 0.54 & 0.48 & 0.48 & 0.48 & 0.48 & 0.50 & 0.51 \\
\hline Threonine & 0.81 & 0.83 & 0.82 & 0.81 & 0.81 & 0.81 & 0.80 & 0.79 & 0.78 & 0.79 & 0.78 & 0.78 \\
\hline Cost (Rs.per kg) & 28.60 & 25.67 & 24.58 & 23.67 & 23.00 & 22.32 & 28.03 & 25.60 & 24.56 & 23.47 & 22.62 & 22.07 \\
\hline
\end{tabular}


Table.2 Ingredients and nutrient composition of finisher diets (3-6 wk)

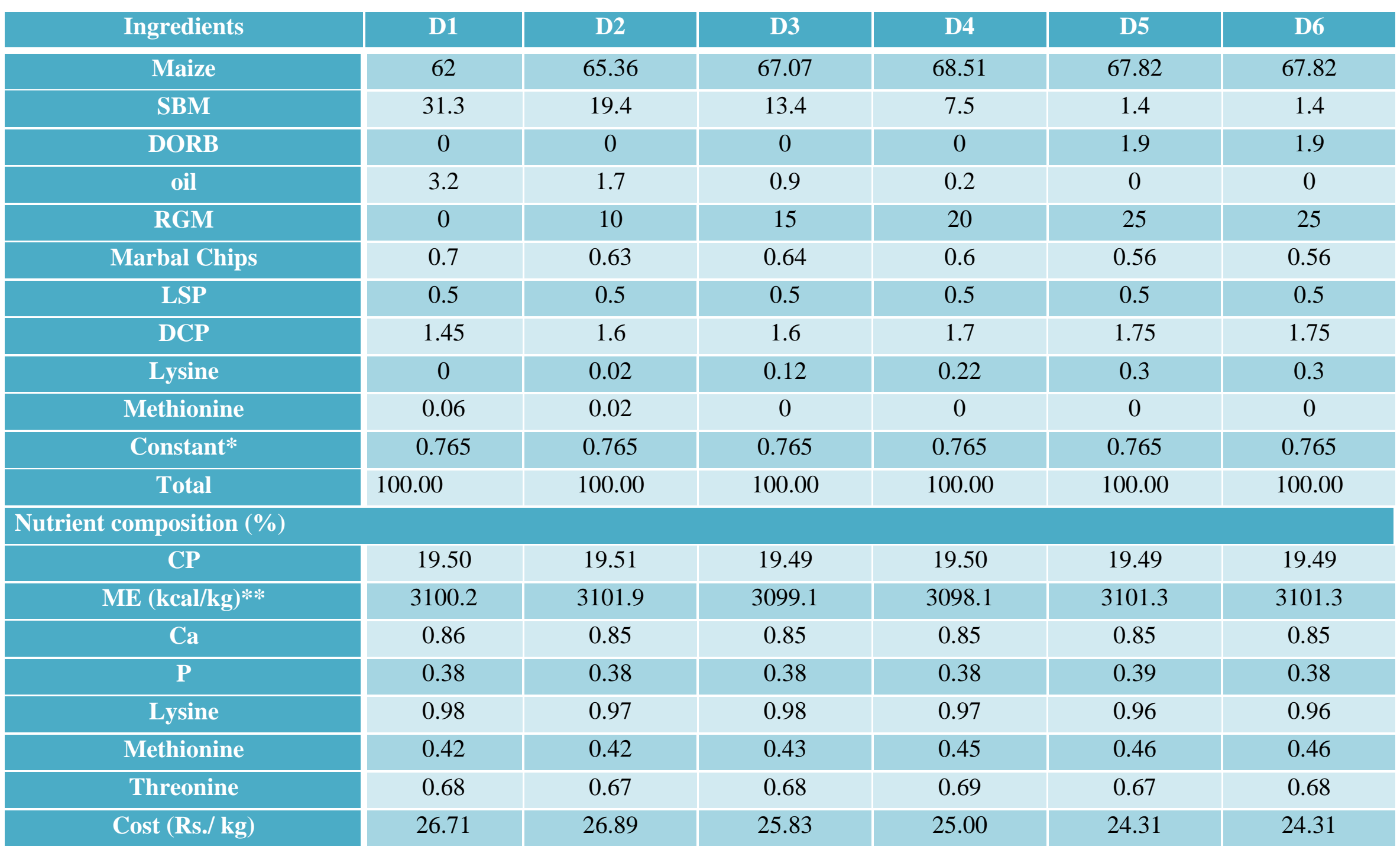

In finisher diet *Constant 0.77 includes salt $0.4 \%$, trace mineral premix $0.1 \%$, vitamin premix $0.15 \%$, vit. B complex $0.015 \%$, choline chloride $0.05 \%$ and toxin binder $0.05 \%$. (As per ICAR, 2013) **calculated value 
Table.3 Effect of feeding different levels of RGM on haematological parameters

\begin{tabular}{|c|c|c|c|c|c|c|c|c|}
\hline Treatment & T1 & $\mathbf{T} 2$ & T3 & $\mathrm{T} 4$ & T5 & T6 & Pooled SEM & P value \\
\hline RGM (\%) & 0 & 10 & 15 & 20 & 25 & 30 & & \\
\hline WBC & 22.7 & 22 & 22.7 & 22.7 & 21.8 & 19.7 & 0.461 & NS \\
\hline Neutro. & 5.1 & 5.3 & 5.7 & 5 & 5.1 & 5.1 & 0.145 & NS \\
\hline Lym. & 15 & 14.2 & 14.7 & 15.4 & 14.1 & 12.4 & 0.35 & NS \\
\hline Mono. & 1.3 & 1.1 & 1.1 & 1.1 & 1.2 & 1.1 & 0.033 & NS \\
\hline Neutro. \% & 22.3 & 24.2 & 24.8 & 22.2 & 23.3 & 26.2 & 0.533 & NS \\
\hline Lym\% & 66.5 & 65 & 64.8 & 67.4 & 64.3 & 63 & 0.647 & NS \\
\hline Mono.\% & 5.8 & 5.2 & 5 & 5 & 5.6 & 5.7 & 0.179 & NS \\
\hline H:L & 0.34 & 0.38 & 0.39 & 0.33 & 0.37 & 0.42 & 0.011 & NS \\
\hline $\mathbf{R B C}$ & 2.2 & 2.3 & 2.3 & 2.3 & 2.4 & 2.3 & 0.028 & NS \\
\hline $\mathbf{H b}$ & 9.3 & 10.4 & 9.6 & 10 & 10.2 & 9.5 & 0.143 & NS \\
\hline PCV\% & 24.1 & 25.8 & 25.8 & 26.2 & 26.6 & 25.1 & 0.328 & NS \\
\hline $\mathrm{MCV}$ & 110 & 111 & 111 & 113 & 111 & 112 & 0.538 & NS \\
\hline RDWc & 12.2 & 11.3 & 12.6 & 12.4 & 11.6 & 12.6 & 0.262 & NS \\
\hline MCH & 42.6 & 44.7 & 41.4 & 43.3 & 42.8 & 42.5 & 0.373 & NS \\
\hline $\mathrm{MCHC}$ & 38.6 & 40.2 & 37.2 & 38.1 & 38.4 & 37.8 & 0.275 & NS \\
\hline PDWc & 32.7 & 32.4 & 31.6 & 32.5 & 31.3 & 31.4 & 0.383 & NS \\
\hline PLT & 29.3 & 27.8 & 27.3 & 28.3 & 30.5 & 24.8 & 0.746 & NS \\
\hline PLT \% & 0.29 & 0.28 & 0.27 & 0.28 & 0.31 & 0.25 & 0.007 & NS \\
\hline MPV & 8.9 & 8.6 & 7.9 & 8.6 & 9.6 & 8.2 & 0.173 & NS \\
\hline
\end{tabular}

Units: WBC (X 10 $\left.0^{4} \mathrm{ul}\right), \mathrm{RBC}\left(\mathrm{X} 10^{6} \mathrm{ul}\right), \mathrm{Hb}(\mathrm{g} / \mathrm{dl}), \mathrm{MCV}(\mathrm{fl}), \mathrm{MCH}(\mathrm{pg}), \mathrm{MCHC}(\mathrm{g} / \mathrm{dl})$ and PLT (X10 $\left.3 \mathrm{ul}\right)$, NS-Non significant (P>0.05) 
Table.4 Effect of feeding different levels of RGM on serum biochemical parameters

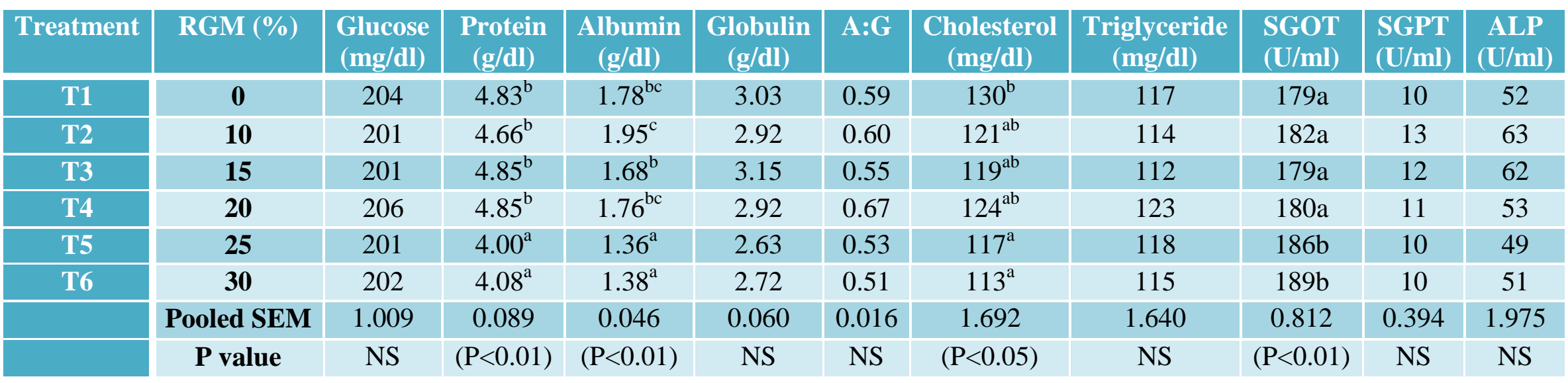

Values bearing different superscripts within the column differ significantly, NS-Non-significant $(\mathrm{P}>0.05)$

Table.5 Effect of feeding different levels of RGM on carcass traits (\% live wt.) and body coloration

\begin{tabular}{|c|c|c|c|c|c|c|c|c|c|c|c|c|}
\hline Treatment & $\begin{array}{l}\text { RGM } \\
(\%)\end{array}$ & Skin color & $\begin{array}{l}\text { Shank } \\
\text { color }\end{array}$ & $\begin{array}{l}\text { Blood } \\
\text { loss }\end{array}$ & $\begin{array}{l}\text { Feather } \\
\text { loss }\end{array}$ & Spleen & Bursa & $\begin{array}{l}\text { Thymu } \\
\text { s }\end{array}$ & Drumstick & Back & Wings & Neck \\
\hline T1 & $\mathbf{0}$ & 3.75 & 5.25 & 2.9 & 9.3 & 0.21 & 0.13 & 0.31 & 10.3 & 15.8 & 8.2 & 4.9 \\
\hline $\mathrm{T} 2$ & 7.5 & 4.00 & 4.75 & 3.1 & 9.3 & 0.24 & 0.10 & 0.25 & 10.6 & 16.2 & 8.5 & 4.9 \\
\hline T3 & 10 & 4.00 & 5.25 & 2.8 & 9.3 & 0.26 & 0.11 & 0.28 & 10.7 & 15.8 & 8.5 & 4.9 \\
\hline $\mathrm{T} 4$ & 12.5 & 4.00 & 5.25 & 3.5 & 9.3 & 0.25 & 0.10 & 0.25 & 9.9 & 16.2 & 8.3 & 4.7 \\
\hline & 15 & 4.00 & 5.50 & 2.8 & 9.1 & 0.25 & 0.12 & 0.35 & 10.4 & 16.7 & 8.2 & 4.5 \\
\hline & $\begin{array}{l}\text { Pooled } \\
\text { SEM }\end{array}$ & 4.25 & 5.50 & 2.7 & 8.8 & 0.25 & 0.13 & 0.30 & 10.0 & 16.3 & 8.8 & 4.8 \\
\hline & P value & 0.15 & 0.11 & 0.084 & 0.078 & 0.009 & 0.006 & 0.012 & 0.087 & 0.111 & 0.067 & 0.051 \\
\hline & & NS & NS & NS & NS & NS & NS & NS & NS & NS & NS & NS \\
\hline
\end{tabular}


Haematological parameters did not show any significant $(\mathrm{P}>0.05)$ difference as compared to control and other dietary treatments. All the values of various haematological parameters were ranges between normal physiological values up to $30 \%$ inclusion level of RGM. No references are available in the literature regarding effect of RGM on haematological parameters of broiler.

\section{Serological parameters}

The data pertaining to influence of different levels of RGM feeding to broilers on serological parameters have been presented in table 4. Serum glucose, globulin, triglycerides, serum enzymes SGPT and alkaline phosphatase did not exhibit any significant $(\mathrm{P}>0.05)$ difference as compared to control. Serum total protein, albumin and SGOT decreased significantly $(\mathrm{P}<0.01)$ in 25 and $30 \%$ RGM groups as compared to control. Serum cholesterol decreased significantly $(\mathrm{P}<0.05)$ in 25 and $30 \%$ RGM groups as compared to control. All the values of various serological parameters were ranges between normal physiological values up to $20 \%$ inclusion level of RGM. Lower serum total protein and albumin levels at 25 and $30 \%$ inclusion levels may be due to poor digestibility of RGM protein as compared to soybean meal at higher inclusion levels. Metwally and Farhat (2015) who reported no significant $(P>0.05)$ difference in serum biochemical parameters (serum lipid profile, glucose, total protein, albumin and globulin) up to addition of $12.5 \%$ RGM in diet of broiler chicken. Kumar et al., (2016) also reported no difference in the serological variables (glucose, blood urea nitrogen, plasma proteins and non-esterified fatty acids) on addition of RGM up to $21 \%$ level in the diet of growing dairy calves. Our results were in agreement with Metwally and Farhat (2015) and Kumar et al., (2016). All the values of various serological parameters were ranges between normal physiological values up to $20 \%$ inclusion level of RGM.

\section{Carcass traits}

The data pertaining to influence of different levels of RGM feeding to broilers on carcass traits have been presented in table 5. Carcass traits in terms of immune organ weight (spleen, bursa and thymus), cut up parts, feather and blood loss (\%), skin and shank coloration did not show any significant ( $\mathrm{P}>0.05)$ difference as compared to control. Our results are in agreement with Sherazi et al., (1995) who reported no significant $(\mathrm{P}>0.05)$ difference in dressing percentage on incorporation of RGM up to $10 \%$ level. Metwally and Farhat (2015) also reported no significant $(\mathrm{P}>0.05)$ difference in dressing percentage and internal organs on addition of RGM up to $12.5 \%$ level in the diet of broiler chicken. It can be concluded that inclusion of RGM up to $30 \%$ in the diet had no adverse effects on carcass traits, cut-up parts and internal organs of broiler chicken.

Thus, it is concluded that rice gluten meal (RGM) can safely incorporated at the inclusion level of $20 \%$ in broiler diet without any adverse effect on haematological, serum biochemical and carcass traits.

\section{Acknowledgement}

ICAR-Central Avian Research Institute, Izatnagar, Utter Pradesh-243122 for providing all necessary inputs and facilities.

\section{References}

Agricultural Statistics 2015-16. Directorate of Economics and Statistics. Department of Agriculture, Cooperation and Farmers welfare. Government of India, New Delhi. 
AOAC 2000. Association of Official Analytical Chemists. Official Methods of Analysis.17th edn, Washington, DC.

Duncan, D.B. 1955. Multiple range and F tests. Biometrics. 11: 1-42.

Gopalkrishnan, M.V. and Jamuna, P. 2000. Optimum time requirement for enzymatic hydrolysis of food proteins. J. Food Sci. Tech.37: 319-322.

Hill, F.W. and Anderson, D.L. 1958. Comparison of metabolizable energy and productive energy determination with the chicks. Journal of Nutrition. 64: 587-603.

ICAR 2013.Nutrient requirements of Animals-Poultry (ICAR-NIANP). 1: 1316.

Kumar, R., Thakur, S.S. and Mahesh, M.S. 2016. Rice gluten meal as an alternative by-product feed for growing dairy calves. Trop Anim. Health Prod. Sringer. 48 (3): 619-624.

Malik, T.A., Thakur, S.S., Mahesh, M.S. and Yogi, R.K. 2017.Replacing groundnut cake with gluten meals of rice and maize in diets for growing Sahiwal cattle. Asia-Aus. J. Anim. Sci. 30(10): 1410.

Metwally A and Farahat M., 2015. Nutritive value and feeding of rice gluten meal in broiler chickens. Res. Opin. Anim. Vet. Sci., 5(11): 443-451.

Sherazi, T.H., AIam, M.Z., GiIani, A.H. and Nawaz, H. 1995. Graded replacement of fish meal with rice protein meal in broiler ration. Pak. J. Agri. Sci. 32: 2-3.

Snedecor, G.W. and Cochran, W.G. 1989. Statistical Methods. 7th edn. Oxford and IBH.

Talpatra, S.K., Roy, S.C. and Sen, K.C. 1940. Estimation of Phosphorus, Chlorine, Calcium, Magnesium, Sodium and Potassium in feed stuffs. Indian Journal of Veterinary Science, 10: 243-258.

Van Soest, P.J. and Wine R.H. 1967. Use of detergents in the analysis of fibrous feeds. IV. Determination of plant cell wall constituents. J. Asso. Agri. Chem., 50: 50-56.

\section{How to cite this article:}

Dinani, O.P., Pramod Kumar Tyagi, A.B. Mandal, Praveen Kumar Tyagi, J.S. Tyagi and Dukare Sagar Popat. 2018. Effect of Feeding Rice Gluten Meal (RGM) on Haematological, Serum Biochemical and Carcass Traits in Broilers. Int.J.Curr.Microbiol.App.Sci. 7(05): 378386. doi: https://doi.org/10.20546/ijcmas.2018.705.049 